\title{
THE EFFECTS OF GADGETS ON THE OCCURRENCE OF ANEMIA IN TEENAGE GIRLS
}

\author{
Juhrotun Nisa ${ }^{1)}$, Adevia Maulidya Chikmah ${ }^{2)}$, Riska Arsita Harnawati ${ }^{3)}$ \\ E-mail: nisa.jn20@gmail.com \\ ${ }^{1,2,3}$ Program Studi DIII Kebidanan, Politeknik Harapan Bersama Tegal, Indonesia \\ Jln. Mataram No.09 Pesurungan Lor Kota Tegal \\ Telp/Fax (0283)352000
}

\section{Article Information}

Received:

September 27, 2019

Revised:

January 06, 2020

Accepted:

January 19, 2020

Available online:

January 23, 2020

\begin{abstract}
The prevalence of anemia in Indonesia, namely in teenager women, was $26.50 \%$ and in women of childbearing age by $26.9 \%$. In addition to eating patterns, teenagers were now starting to depend on the development of existing technology. Lifestyle had an impact on the incidence of anemia. The purpose of this study was to determine the effect of gadgets on the incidence of anemia in teenager girls. This research was an analytical survey study with a cross-sectional design, conducted from June to August 2019 at SMK 1 Kota Tegal. The sampling technique used was total sampling with a sample of 40 young women in the Department of Catering. Data collection in this study used a questionnaire, while data analysis was carried out univariate and bivariate with chi-square. The results showed that the use of gadgets for 4-5 hours/day had anemia as much as $55.6 \%$, and $78.9 \%$ of anemia in the use of gadget $2-3$ hours/day. The use of gadgets with a duration of 4-5 hours/day and poor eating patterns as much as $88.9 \%$ and $57.9 \%$ of respondents on the duration of use of 2-3 hours/day. There is an influence between the duration of the use of gadgets on eating patterns ( $\mathrm{p}$ value $=0.005)$, and there is an influence between the use of gadgets on the incidence of anemia ( $p$-value $=0.037$ ). The more widespread use of gadgets, it is necessary to have support from across sectors such as teachers and parents always to remind and limit smartphone usage.
\end{abstract}

Keywords : Gadgets, anemia

\section{Introduction}

Anemia is a nutritional problem in the world, especially in developing countries, including Indonesia. The iron nutrition anemia rate in Indonesia was $72.3 \%$. Iron deficiency in teenagers results in pale, weak, tired, dizzy, and decreased concentration of learning. The causes, among others: the level of parental education, economic level, the level of knowledge about anemia from teenage girls, consumption of $\mathrm{Fe}$, Vitamin $\mathrm{C}$, and the length of menstruation. The prevalence of anemia in Indonesia, namely in young women by $26.50 \%$, in women of childbearing age by $26.9 \%$, in pregnant women by $40.1 \%$ and in infants by $47.0 \% .^{[1]}$

The emergence of anemia can be caused by intake of the wrong diet, irregular and out of balance with the adequacy of nutritional sources needed by the body including energy intake, protein intake, carbohydrate intake, fat intake, vitamin $\mathrm{C}$ and especially the lack of food sources that contain iron, and 
folic acid. Efforts that can be done in overcoming the problem of anemia in teenagers, one of which is to improve the intake of foods containing iron. ${ }^{[2]} \mathrm{A}$ study conducted by Nisa et al. (2019) stated that the habit of consuming fruits and vegetables before pregnancy had a significant relationship with the incidence of anemia in pregnancy. Based on these studies, it was necessary to pay attention to the food consuming since before pregnancy, one of which was food consumed by teenagers. The attention to the nutritional status of expectant mothers since adolescence was expected to break the chain of anemia in pregnancy. ${ }^{[3]}$

In addition to eating patterns, teenagers are now starting to depend on the development of existing technology. The development of this technology seems to make it easier for them in various fields, especially in telecommunications, which often referred to as gadgets. Teenagers use gadgets/cellphones in various activities; one of them is social media, which is a trend among teenagers. ${ }^{[4]}$

Online media can provide many benefits if used appropriately, including preventing and managing anemia. This statement stated by Saraswati (2019), where the use of the "aneminfo" application, which is an android mobilebased education media, can change/enhance the knowledge and attitudes of young women in preventing anemia. ${ }^{[5]}$

Nowadays, almost all teenagers already had gadgets, and when they were addicted to it, in a day, they used it for about 6-8 hours. Usually, they accessed in the form of social media, Facebook, Twitter, Instagram, games, the internet, and just sending messages. Many people think that the gadget was a part of their lives, so wherever, they often carried their smartphone. Gadgets unwittingly harm teenagers, one of them on health conditions. Tarigan (2018) states that lifestyle has a significant influence on the incidence of anemia in adolescent girls. $^{[6]}$
Teenage girls too often interact with gadgets that make them more often late even to forget to eat, which might have an impact on hemoglobin levels, so a study needs to be done to determine the effect of gadgets on the incidence of anemia in adolescent girls.

\section{Method}

The study design used a cross-sectional study, which is a research design whose measurements and observations were carried out simultaneously at one time (once).

This type of study was an analytic survey that is a survey or study that tries to explore health phenomena that can occur. The population in this study were teenage girls who experienced anemia during the study. The sampling technique used in this study was total population / saturated sampling, which was all young women who meet the criteria were used as a population and sample. This study was conducted from June to August 2019 at SMK 1 Tegal City with a sample of 40 female teenagers from the Department of Catering. The bivariate analysis used in this study was the Chi-Square Test.

\section{Results and discussion}

Table 1 Respondents' Characteristics

\begin{tabular}{|c|c|c|c|c|}
\hline \multirow{2}{*}{$\begin{array}{l}\text { No. } \\
1\end{array}$} & \multicolumn{2}{|c|}{ Variable } & \multirow{2}{*}{$\begin{array}{l}\mathbf{f} \\
14\end{array}$} & \multirow{2}{*}{$\begin{array}{c}\% \\
35.0\end{array}$} \\
\hline & Anemia & Anemia & & \\
\hline & Status & $\begin{array}{l}\text { Not } \\
\text { Anemia }\end{array}$ & 26 & 65.0 \\
\hline \multirow[t]{3}{*}{2} & Age & 14 & 8 & 20.0 \\
\hline & & 15 & 26 & 65.0 \\
\hline & & 16 & 6 & 15.0 \\
\hline \multirow[t]{2}{*}{3} & Gadget & Yes & 40 & 100.0 \\
\hline & Ownership & Not & 0 & 0 \\
\hline \multirow[t]{2}{*}{4} & Number of & 1 & 36 & 90.0 \\
\hline & Gadgets & 2 & 4 & 10.0 \\
\hline \multirow[t]{3}{*}{5} & $\begin{array}{l}\text { Time Using } \\
\text { Gadgets }\end{array}$ & $\begin{array}{l}4-5 \\
\text { hours/da }\end{array}$ & 18 & 45.0 \\
\hline & & $\begin{array}{l}\mathrm{y} \\
2-3 \\
\text { hours/da }\end{array}$ & 19 & 47.5 \\
\hline & & $\begin{array}{l}\mathrm{y} \\
\leq 1 \\
\text { hours/da } \\
\mathrm{y}\end{array}$ & 3 & 7.5 \\
\hline
\end{tabular}




\begin{tabular}{lllrr}
\hline $6 \quad$ Number of & 1 & 16 & 40.0 \\
& Applications & 2 & 10 & 35.0 \\
& Accessed & 3 & 11 & 27.5 \\
& & 4 & 2 & 5.0 \\
& & 5 & 1 & 2.5 \\
7 & Frequently & 1 & 30 & 75.0 \\
& Accessed & 2 & 7 & 17.5 \\
& Applications & 3 & 3 & 7.5 \\
\hline
\end{tabular}

Based on table 1, it shows that $35 \%$ of teenage girls had anemia, $65 \%$ of respondents were 15 years old, $100 \%$ had gadgets with $90 \%$ of them having one gadget, where the duration of use was $45 \%$ for $4-5$ hours/day, and $40 \%$ only use one application and $75 \%$ only one application that used frequently.

The incidence of anemia in teenage girls was quite high; it can occur because, during puberty, teenage girls experienced a loss of much iron during menstruation. Besides that, the need for iron absorption peaked at the age of 1415 years old. This study is in line with a study conducted by Afridayanti and Ayuningtyas (2016) which showed that $21.5 \%$ of teenage girls experienced anemia. ${ }^{[7,8]}$

Gadgets are trendy at this time by all circles, thus encouraging gadget developers to make an innovation in the appearance, application, and shape to make it more attractive to consumers, especially for students. According to experts, the impact of the progress and renewal of this technology on the social field was social behavior, where this social behavior is an atmosphere of interdependence, which is a necessity to guarantee human existence. ${ }^{[9]}$

A study conducted by UNICEF (2012) showed that $80 \%$ of children and teens were internet users, where $52 \%$ of them accessed the internet from mobile phones, $21 \%$ from smartphones, and $4 \%$ from tablets. The reasons for using the internet were to find information, to communicate/connect with friends and as entertainment. ${ }^{[10]}$
Table 2 Description of Gadgets Usage

\begin{tabular}{|c|c|c|c|c|}
\hline No. & Variable & & f & $\%$ \\
\hline \multirow[t]{2}{*}{1} & \multirow{2}{*}{$\begin{array}{l}\text { Check } \\
\text { cellphone } \\
\text { between } \\
\text { lessons }\end{array}$} & Yes & 13 & 32.5 \\
\hline & & Not & 27 & 67.5 \\
\hline \multirow[t]{2}{*}{2} & \multirow{2}{*}{$\begin{array}{l}\text { Prefer doing } \\
\text { homework } \\
\text { rather than } \\
\text { gadgets }\end{array}$} & Yes & 19 & 47.5 \\
\hline & & Not & 21 & 52.5 \\
\hline \multirow[t]{2}{*}{3} & \multirow{2}{*}{$\begin{array}{l}\text { Get annoyed } \\
\text { when } \\
\text { someone } \\
\text { interferes } \\
\text { with the } \\
\text { gadget }\end{array}$} & Yes & 20 & 52.5 \\
\hline & & Not & 19 & 47.5 \\
\hline \multirow[t]{2}{*}{4} & \multirow{2}{*}{$\begin{array}{l}\text { Feel } \\
\text { comfortable } \\
\text { interacting } \\
\text { through } \\
\text { gadgets }\end{array}$} & Yes & 16 & 40.0 \\
\hline & & Not & 24 & 60.0 \\
\hline \multirow[t]{2}{*}{5} & \multirow{2}{*}{$\begin{array}{l}\text { Feeling } \\
\text { anxious } \\
\text { when not } \\
\text { using the } \\
\text { gadget }\end{array}$} & Yes & 13 & 32.5 \\
\hline & & Not & 27 & 67.5 \\
\hline
\end{tabular}

Based on table 2, it showed that $32.5 \%$ of respondents checked cellphone between lessons, $52.5 \%$ prioritize gadgets rather than homework, $52.5 \%$ claim to be annoyed when someone interferes with the gadget, $40 \%$ claim to be more comfortable interacting through gadgets, and $32.5 \%$ feel anxious when not using gadgets.

A study conducted by Rohmah (2017) showed that there was a positive influence between the use of gadgets with students ' motivation/interest in learning. It can also be interpreted that the use of gadgets had a bad influence on students' interest in learning. It could happen because students tend to open/use $\neg$ gadgets to access the internet, social media, chat, and other applications during lesson hours ${ }^{[11]}$.

Students characters who actively use gadgets (smartphones) experience a decline and degradation of their character values. They tend to be more apathetic, looking for easy, lack sympathy and can make them have a stubborn nature. Based on the analysis of 
observations, questionnaires, and interviews also mentioned that the character of students who actively used gadgets (smartphones) experienced a decline and degradation of their character values. They tend to be more apathetic, and their mindset tends to be irrational, looking for ease, lacking sympathy. ${ }^{[9]}$

The use of mobile phones that are too often can have an impact on health, one of which is anemia. That is because when using a cell phone, people tend to focus on the application used as if finding their comfort so that they forget to consume food needed by their bodies.

\section{Bivariate Analysis}

Table 3 Effect of Gadgets on Diet

\begin{tabular}{|c|c|c|c|c|c|c|}
\hline \multirow[t]{2}{*}{ Variable } & \multicolumn{2}{|c|}{$\begin{array}{c}\text { Poor Eating } \\
\text { patterns }\end{array}$} & \multicolumn{2}{|c|}{$\begin{array}{c}\text { Good } \\
\text { Eating } \\
\text { patterns }\end{array}$} & \multirow[t]{2}{*}{$\sum$} & \multirow[t]{2}{*}{$\begin{array}{c}\text { p- } \\
\text { value }\end{array}$} \\
\hline & f & $\%$ & f & $\%$ & & \\
\hline $4-5$ & 1 & 88.9 & 2 & 11.1 & 1 & \\
\hline Hours/day & 6 & & & & 8 & \\
\hline $2-3$ & 1 & 57.9 & 8 & 42.1 & 1 & 0.00 \\
\hline Hours/day & 1 & & & & 9 & 5 \\
\hline $\begin{array}{c}\quad \leq 1 \\
\text { Hours/day }\end{array}$ & 0 & 0 & 3 & 100 & 3 & \\
\hline
\end{tabular}

Based on the table above, it showed that respondents who used gadgets for 45 hours/day with poor eating patterns were $88.9 \%$, respondents who used gadgets 2-3 hours/day with poor eating patterns were $57.9 \%$ and respondents who used gadgets an hour with a good eating pattern were $100 \%$. Bivariate analysis results obtained p-value 0.005 means that there is an influence between the duration of the use of gadgets on eating patterns.

A study conducted by Tiaki and Ismarwati (2017) showed that teens who had a poor eating pattern and had anemia were $43.4 \%$. Eating patterns also had a significant relationship with the incidence of anemia. ${ }^{[12]}$

The use of gadgets for a long time can make teenage girls discover the world and their comfort and sometimes forget to eat. They are too absorbed in using gadgets, and some teens also prefer to buy internet quota than to buy food according to their body's needs, which affects the lack of frequency of consuming food.

The existence of advertisements for fast food products or the latest lifestyle in the media can influence consumption patterns or even lifestyles in general. Advertisements through mass media will support teenagers in food selection. Children and adolescents tend to consume a lot of the advertised food, and these foods contain high salt, sugar, fat, calories, and carbonated drinks ${ }^{[13]}$.

The influence of screen-time viewing with diet shows significant results (p-value <0.05). Respondents with high screen-time viewing had poor eating patterns, especially those with malnutrition. The group of respondents who had poor eating patterns and had malnutrition was had an imbalance in the consumption of vegetables, fruits, sugar, salt, and fat. Respondents tend to be less in the consumption of vegetables and fruit and more in the consumption of sugar, salt, and fat. ${ }^{[14]}$

The number of contemporary foods sold through social media also becomes an inhibiting factor for iron absorption, such as drinks made from coffee and tea. This statement is in line with a study conducted by Masthalina et al. (2015), which stated that there was a significant relationship between factor consumption $\mathrm{Fe}$ inhibitors with anemia ${ }^{[15]}$. Poor eating patterns have an impact on the unmet needs of the body of teenage girls, one of which is the need for iron, and the inhibiting factor consumed. The presence of inhibiting factors that consumed every day can also affect the incidence of anemia

Table 4 Effect of Gadgets on Anemia

\begin{tabular}{|c|c|c|c|c|c|c|}
\hline \multirow[t]{2}{*}{ Variable } & \multicolumn{2}{|c|}{ Anemia } & \multicolumn{2}{|c|}{$\begin{array}{c}\text { Not } \\
\text { Anemia }\end{array}$} & \multirow[t]{2}{*}{$\sum$} & \multirow{2}{*}{$\begin{array}{c}\text { p- } \\
\text { value }\end{array}$} \\
\hline & f & $\%$ & f & $\%$ & & \\
\hline $4-5$ & 10 & 55.6 & 8 & 44.4 & 18 & \\
\hline Hours/day & & & & & & \\
\hline $\begin{array}{c}2-3 \\
\text { Hours/day }\end{array}$ & 4 & 21.1 & 5 & 78.9 & 19 & 0.037 \\
\hline $\begin{array}{c}\leq 1 \\
\text { Hours/day }\end{array}$ & 0 & 0 & 3 & 100 & 3 & \\
\hline
\end{tabular}


Based on table 4 above, it shows that respondents who used gadgets for 45 hours/day experienced anemia were $55.6 \%$, and respondents who used gadgets 2-3 hours/day and had anemia were $21.1 \%$, while respondents who used gadgets $\leq$ an hour were $100 \%$ did not have anemia. Bivariate analysis results obtained p-value 0.037 , meaning that there is an influence between the duration of the use of gadgets on the incidence of anemia. The result is in line with a study conducted by Tarigan (2018), stated that there was a relationship between the use of gadgets and the incidence of anemia. ${ }^{[6]}$

Advances in technology in the current era make the millennial generation dependent on the presence of gadgets. Teenagers can not be separated from the smartphone even to take it to school and open it between lessons. The allowance, which used to buy food at school, is being used to buy their internet needs for the sake of lifestyle and to put aside other needs, including to meet the nutritional needs in their body.

The frequency of eating that is lacking makes iron needs that must be fulfilled by teenage girls not being met every day. And the presence of contemporary snacks that are trendy on social media also sometimes can inhibit the absorption of iron, which can cause anemia in teenage girls. The frequency of eating that is lacking makes iron needs that must be fulfilled by teenage girls not being met every day. Moreover, the presence of contemporary snacks that are trendy on social media also can sometimes inhibit the absorption of iron, which can cause anemia. This statement is in line with Sanjaya (2017), which showed that social media influenced 80 $\%$ of consumption patterns, but contrary to Khoiriani's statement (2017) that there was no significant relationship between eating behavior and nutritional status with the use of Instagram culinary accounts. ${ }^{[16,17]}$

\section{Conclusion}

Teenage girls who experienced anemia in the use of gadgets for 4-5 hours/day were $55.6 \%$, and $78.9 \%$ were using about 2-3 hours/day. Teenage girls who had a poor diet on using gadgets 4-5 hours/day were $88.9 \%$, and $57.9 \%$ used it about 2-3 hours/day. There is an influence between the duration of the use of gadgets on eating patterns $(\mathrm{p}$-value $=$ 0.005 ), and there is an influence between the use of gadgets on the incidence of anemia ( $p$-value $=0.037$ ). There needs to support from across sectors like teachers and parents in reminding and limiting the use of gadgets. It can be applied with regulations or agreements made between teachers/parents and teenagers about the limits of smartphone usage.

\section{References}

[1] Burner. Faktor-Faktor Yang Berhubungan Dengan Kejadian Anemia Pada Remaja Putri. 2012. Jurnal di akses tanggal 15 Februari 2013.

[2] Fitriani. Anemia dan Remaja?. 2014.

https://dhaifinafitrianiii.blogspot.c om/2014/06/anemia-dan-

remaja.html

[3] Nisa, J., Chikmah, A.M., Zulfiana, E. Perilaku Konsumsi Sumber Enhancer Dan Inhibitor Fe dengan Kejadian Anemia Pada Kehamilan. Siklus: Journal Research Midwifery Politeknik Tegal. 2019. 8 (1), 41-47

[4] Patimah.S. Gizi Remaja Putri Plus 1000 Hari Pertama Kehidupan. Edisi1. Bandung. 2017.

[5] Saraswati, Rizki Septia. Pengaruh Aplikasi Android "Aneminfo" Terhadap Pengetahuan Dan Sikap Remaja Putri Terkait Pencegahan Anemia Defisiensi Besi Undergraduate thesis. Semarang: Diponegoro University. 2019

[6] Tarigan. Hubungan Gaya Hidup Remaja Terhadap Kejadian Anemia Pada Remaja Putri Kelas $X$ Di SMA Negeri 2 Binjai Tahun 
2018. Jurnal Mutiara Pendidikan Indonesia. 2018. Vol 4 No 1.

[7] Afridayanti, Nindita Ayu , Dan Ayuningtyas, Ika Fitria. Gambaran Kejadian Anemia Pada Remaja Putri Berdasarkan IMT Di Puskesmas Pakem Kabupaten Sleman. Karya Tulis Ilmiah. Yogyakarta: Stikes Jenderal Achmad Yani. 2017

[8] WHO. Prevention of Iron Deficiency Anemia in Teenagers: Role of Weekly Iron and Folic Acid Suplementation. 2011.

[9] Rahmandani, F., Tinus, A., Ibrahim, M. Mansur. Analisa Dampak Penggunaan Gadget (Smartphone) Terhadap Kepribadian dan Karakter (KEKAR) Peserta Didik Di SMA Negeri 9 Malang. Jurnal Civic Malang. Volume 3 Nomor 1, Mei, 2018: 18-44.

[10] UNICEF. Indonesian Youth Online An Exploratory Study of the Indonesian Digital Landscape. 31 Januari 2012.

[11] Rohmah, Chusna Oktia. Pengaruh Penggunaan Gadget Dan Lingkungan Belajar Terhadap Minat Belajar Siswa Kelas Xi Kompetensi Keahlian Administrasi Perkantoran SMK MUHAMMADIYAH

2

Yogyakarta. Skripsi. Yogyakarta: Universitas Negeri Yogyakarta. 2017.

[12] Tiaki dan ismarwati. Hubungan Pola Makan dengan Kejadian Anemia Pada Remaja Putri Kelas XI di SMK N 2 Yogyakarta. Naskah Publikasi. Yogyakarta: Universitas Aisiyah Yogyakarta. 2017.

[13] Wardlaw, Jeffrey H. Perspectives in Nutrition. New York: McGraw-Hill, Inc.; 2007
[14] Kumalawati, Margawati, Rahadiyanti. Hubungan Antara Durasi Penggunaan Alat Elektronik (Gadget), Aktivitas Fisik Dan Pola Makan Dengan Status Gizi Pada Remaja Usia 13-15. Journal of Nutrition College. 2019. Volume 8, Nomor 2, Tahun 2019: 73-80

[15] Masthalina, Laraeni Dan Dahlia. Pola Konsumsi (faktor Enhancer Dan Inhibitor $\mathrm{Fe}$ ) terhadap Status Anemia Remaja Putri. KEMAS. Volume 11, Nomor 1, Tahun 2015: 80-86

[16] Sanjaya. Pemanfaatan Media Sosial, Pola Konsumsi Pangan, dan Aktivitas Fisik dalam Hubungan dengan Status Gizi dan Prestasi Belajar Siswa di SMAN 7 Bogor. Skripsi. Bogor: Institut Pertanian Bogor. 2017.

[17] Khoiriani, Izzati Nur. Media Sosial Instagram, Perilaku Makan dan Status Gizi: Studi Pada Kelompok Usia Dewasa Muda di Kabupaten Sleman Yogyakarta. Tesis. Yogyakarta: Universitas Gajah Mada. 2017. 